\title{
Themes of genetic engineering and the homunculus in Patricia Piccinini's sculptural installation, We are Family ${ }^{1}$ \\ Andrew James Smith and Elfriede Dreyer*
}

\begin{abstract}
* Andrew James Smith completed his MA Visual Studies in 2008 at the Department of Visual Arts, University of Pretoria. Elfriede Dreyer is associate professor of Fine Arts at the Department of Visual Arts, University of Pretoria.
\end{abstract}

\begin{abstract}
In this article Patricia Piccinini's We are Family of 2003 is considered in terms of the concept of the genetic homunculus, which can be understood as the product of artifice. The genetically engineered human being is investigated within the context of alchemic and post-human discourse, with specific reference to the ideas of Donna Haraway and Jean Baudrillard. It is maintained that, although it is as yet impossible to accurately predict what the outcomes of such forays into the realms of the natural or the divine may be, post-human futures are already imagined and simulated in the milieu of artistic licence.
\end{abstract}

\section{Introduction}

Just as the creation of life has always been a preoccupation of humankind, so the creation myth is one of humanity's most pervasive archetypes. In mythology, the question of creation is almost always resolved in the divine. Any human attempt at the creation of life is, in most myth systems, portrayed as vainglorious and even perfidious, and human hubris in wishing to acquaint themselves with the divine is mostly met with punishment. This is evident, for example, in the biblical myth of Babel and the ancient Greek myth of Icarus, which both show the symbolic relationship of elevation, divinity and pride.

Similarly, many myths of human annexation of divinity - particularly those of humans creating humans - are tempered by some divine intervention. ${ }^{2}$ It is for this reason that the creation of life and the idea of immortality go hand in hand with the equation of human beings with God. This is most evident in alchemic homunculus mythology which, despite its ancient roots, relates to posthuman theory. ${ }^{3}$ In The post-human condition (1995) Robert Pepperell posits that presentday technology effects fundamental changes in all aspects of human life and society, from arts and culture, to politics and economics.
These areas are becoming increasingly saturated with 'essential' technologies, and all human experience is becoming integrated with increasingly rapidly advancing technology which threatens, on an escalating scale, to overwhelm and destroy humanity. However, this destruction is as inevitable as entropy itself, and is itself an extension of evolution. According to Pepperell (1995:135), the posthuman era begins in full when the output of computers becomes 'unpredictable' and 'all technological progress of human society is geared towards the redundancy of the human species as we know it'.

The loss of distinction between natural and artificial is demonstrable in several post-human technologies. It is in this context that the notion of the homunculus and the work of Patricia Piccinini become relevant.

\section{The homunculus}

The notion of the homunculus, literally meaning 'little man', refers to the generation of human life in the laboratory by the alchemist/ scientist. ${ }^{4}$ Since this feat was, for obvious reasons, never proven to have been performed, the various accounts of and methods for creating the homunculus differ greatly, but most involve specific, mystical prescriptions for the incubation of semen outside the womb of the mother. The genetic homunculus can be understood as the product of any artifice that deals specifically with the creation, perfection, augmentation and prosthesis of human life, where there is mediation of that organism prior to birth. It can be taken to refer to any scientifically created creature produced (partially or wholly) from human DNA that deviates from its original form.

Ontologically, the homunculus is a human construct, an artificial man created solely by human ingenuity and technological prowess. ${ }^{5}$ Originally, the homunculus was created in the retort ${ }^{6}$ using spagyric components and techniques that supposedly nurtured base components into human life. As such, the homunculus was intended as an extension of the alchemist's living soul, a kind of purified cutting that was intended, according to the medieval Arabian alchemist, Jabir Ibn Hayan (Holmyard 1928), to make the alchemist more god-like. The takwin (the ritual creation of life in the laboratory) was a sacred and clandestine rite of purification for Hayan and his adherents, 
that would enable them to attain a greater understanding of God through the appropriation of His processes.

In a similar way, modern scientists arguably prepare genetic hybrids and chimeras in laboratories in equally occult secrecy. The creation of the contemporary genetic homunculus is already a reality: recombinant DNA technology has ensured that animal/ human hybrids - creatures with no root in or connection to nature - are at the forefront of medical research. Like the alchemists of old, today's scientific researchers seek the perfection and immortality of humankind, at least medically. The search for cures to the diseases of the age - HIV/AIDS, cancer and other such terminal nightmares - is conducted alongside cosmetic and experimental research into the human genome.

It is important to distinguish between the genetic homunculus and the genetic clone. Single-cell parthenogenesis (cloning) is not a perfective process. The clone merely represents the cellular twinning of an embryo to create an amoebic doubling of a particular organism, whereas the genetic homunculus is a being that is augmented or changed by science into something that can be perceived as better than the original subject (most often from multiple genetic parents). The genetic homunculus is not a clone, although, like any other life-form, it can be cloned. In fact, it can be argued that the genetic homunculus is not 'human' in any traditional sense. The genetic homunculus can be understood as a being fashioned from altered human DNA, in that it is a combination of specific human traits which have been augmented by science, changed and possibly even hybridised with other species. The result of changing the fundamental nature of what it means to be human, even slightly, is surely a wholly different species. The use of human DNA itself is currently ethically regulated for this very reason.

Fusions of multiple distinct DNA subjects of the same or different species have been dubbed 'chimeras' in the scientific community, after the three-headed monster of Ancient Greek mythology slain by the hero Bellerophon (the Greek monster was a fire-breathing lion with a goat's head on its back and a snake where its tail should be). This kind of hybridisation pre-emptively devalues the sanctity of humanity in a very essential way, since the 'parts' that make up a genetic chimera are interchangeable and thus the process mostly becomes arbitrary ('chimera' is, quite simply, a blanket term for a vastly varied arm of genetic science, comprising any result of recombinant DNA testing). The mere fact that no terminological distinction is drawn between chimeras created using human DNA and other chimeras also lends further opacity to the already clandestine practices of genetic researchers. For this reason it is necessary, even from legal and scientific standpoints, to refer to genetically engineered humans as 'homunculi'.

Superficially, the genetic homunculus may seem similar to American biologist Donna Haraway's cyborg, described in A manifesto for cyborgs: Science, technology and socialist feminism in the 1980s (1991) as a 'cybernetic organism, a hybrid of machine and organism, a creature of social reality as well as a creature of fiction' (1991b:28). Haraway views the cyborg as the offspring of militarism and patriarchal capitalism (1991b:29), and argues:
[By] the late twentieth century, our time, a mythic time, we are all chimeras, theorized and fabricated hybrids of machine and organism; in short, we are cyborgs. The cyborg is our ontology; it gives us our politics. The cyborg is a condensed image of both imagination and material reality, the two joined centers structuring any possibility of historical transformation (1991b:28-29).

Both the genetic homunculus and Haraway's cyborg represent a form of neo-human that is created and prosthesed (augmented by prosthesis) by technology. Both are marriages of technology and nature; and both belong to a separate ethos of non-uniform nature, that is, a nature without laws. The exception is that the genetic homunculus is merely created from human parts, and so it can be argued that it is not specifically human. It is also changed prior to birth and its birth would not occur without the intervention of technology. This is different from the in-vitro fertilisation methods and fertility enhancers of the cyborg. As Baudrillard (1995:70) notes, genetic intervention is a 'definitively integrated prosthesis' and what this means is that there is no longer a distinction between the prosthesis and the prosthesed. The term 'genetic homunculus' describes a being that has benefited from genetic alterations that enhance aspects of its physicality and/or intelligence, where human 
genes have been used only as a point of departure - the genetic homunculus is itself a prosthesis. For example, a genetic homunculus could potentially be a hermaphrodite that can even determine how it reproduces, just as the human cyborg can, but whereas the cyborg is an augmented human and uses its technology to achieve these ends, the technology whereby the genetic homunculus does this is invisible it precedes and mediates its birth.

The crucial element of homunculus mythology is that it concerns life created by humans and represents the efforts of humankind to attain godliness, immortality and perfection. Schwarz (1980:57) states that

in the same way as Prometheus is the mythological archetype of the rebel and Lucifer ... is the theological archetype of the rebel, the alchemist is their human reflection: Prometheus, Lucifer, the alchemist all strive to equal the feats of the gods to reconquer the two complementary qualities: immortality and creativity.

The human creation of life is archetypically significant because it equalises the mortal (humans) and the immortal (gods). As such, the homunculus can be interpreted as the summation of the alchemist/scientist's desire for immortality through his/her own works of authoring an eternal being - a desire to create a race that will see the fusion of nature and culture, a union of humankind and godkind.

The concept of the homunculus represents both the transcendence of what it means to be human, and the ultimate abrogation of nature in humankind's dearest desire - to survive eternally. Visual representations of monstrous creatures created by humans, such as the monster in Mary Shelley's novel, Frankenstein (1818), have been common throughout history. Yet, the homunculus is both sacred and profane and in this sense differs from other monsters inasmuch as it is created by human beings. Still, it offers the hope of transcendence through science and technology, while simultaneously destroying the notion of a creator god and transcendence through spirituality by proving that mortals are capable of the divine. As such it appears monstrous.

In this article it is maintained that, although it is as yet impossible to accurately predict what the outcomes of such forays into the realms of the natural or the divine may be, such futures are already imagined and simulated in the safe milieu of artistic licence. Yet, within the domain of the visual arts, the fanciful and imaginative play with genetic possibilities and abnormalities cannot be viewed as mere artistic divination, but as an important social gauge of cultural norms and attitudes towards the unknown future of human beings.

\section{Patricia Piccinini's homunculi}

Just as there have been countless mythological figures whose magical or technological genesis under human auspices has set them apart from the natural realm, so have these myriad creatures manifested in contemporaneous visual culture. A recent exhibition by Patricia Piccinini recalls the cultural exposition of the monstrous (or, rather, the unknown) with piercing clarity. In her 2003 sculptural installation for the Venice Biennale, We are Family, she offers a strange collection of creatures and corrupted forms, instantly recognisable as artificial, but completely naturalistically represented. One is instantly reminded of the genetic homunculus through the artist's interplay of the natural and artificial, and her life-like presentation of the strange genetic freaks renders her a kind of alchemistartist-scientist. The installation of sculptures of human children interacts nonchalantly with the creatures, ignoring their grotesqueness and treating them with the innocent indifference afforded all well-used playthings. The work comprises several sculptures perched on couches and sofas which are purpose-designed to accommodate them, or sitting on the floor amongst the viewers. The installation consists of several individual pieces which interact directly with the environment and the viewers walking among them, and indirectly with each other.

Reproducing a microcosm of a world completely divorced from normalcy, the artist presents the potentially abominable and horrific aspect of the limitlessness of genetic engineering as banal and commonplace. Still Life with Stem Cells (1) shows a figure of a child playing with or petting curious abortions of form, as if innocently unaware of their grotesqueness. The forms look like preembryonic creatures existing in a bizarre semiliving state (they look alive, yet have no visible means of locomotion, no means to ingest food 


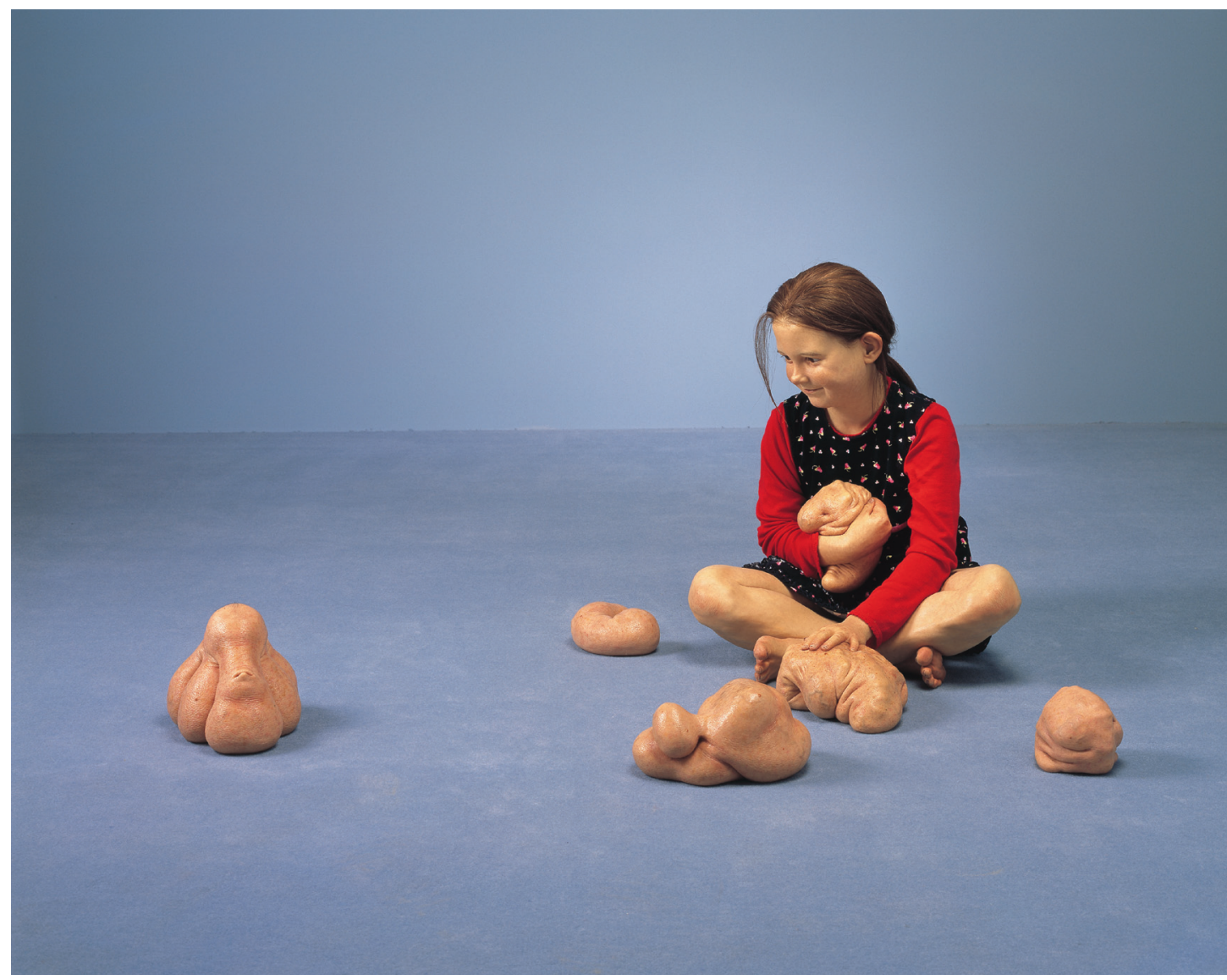

1 Patricia Piccinini, Still Life with Stem Cells (2002). Silicone, polyurethane, human hair, clothing, carpet. Lifesize dimensions variable. Photo: Graham Baring.

or expel waste, or to respire. They appear warm and mammalian, possessing the texture of human skin, yet they have none of the characteristics of a mammal, bearing more of a resemblance to amoebic creatures or embryos).

In reference to Donna Haraway's (1991a:296) idea of nature as topos, accommodating the aberrant, a believable version of nature has been created through the interplay of and negotiation between the unnatural and the natural. The explicit character of the work is ironically where its subtlety lies - the work becomes an exposition of scientific possibility, an exhibit at some kind of futuristic World's Fair. Still Life with Stem Cells reproves the current laxness in scientific ethics, and at the same time questions the relationships of humans to each other, to animals and to possible homunculi that might be born of the manipulation of the human genome.

The alien, pillowy amorphs are reminiscent of the type of natural curiosities one might find in medical museums or universities - only in this work they appear to be presented for amusement, rather than study. What is truly bizarre is that the viewer is acquainted with them as toys or pets, completely pathetic and dominated. One is tempted to see them as wholly non-threatening, helpless lumps, simulacra, of live tissue. Ironically, the 'creatures' do not seem to represent a threat. The threat that they expose is the threat of a violence that humanity will do unto itself and its progenitor, nature. They represent the violence of the system imploding, in reference to the threat of Baudrillard's implosion $(1995: 66,68)$, that is, of the inability to control or make sense of a system that has spiralled out of control, and the threat of the simulacrum made real.

The grotesqueness of the sculptures lies in the spectators' familiarity with the abominated 'creatures'. The children appear to interact smilingly with them, imparting their aura of 


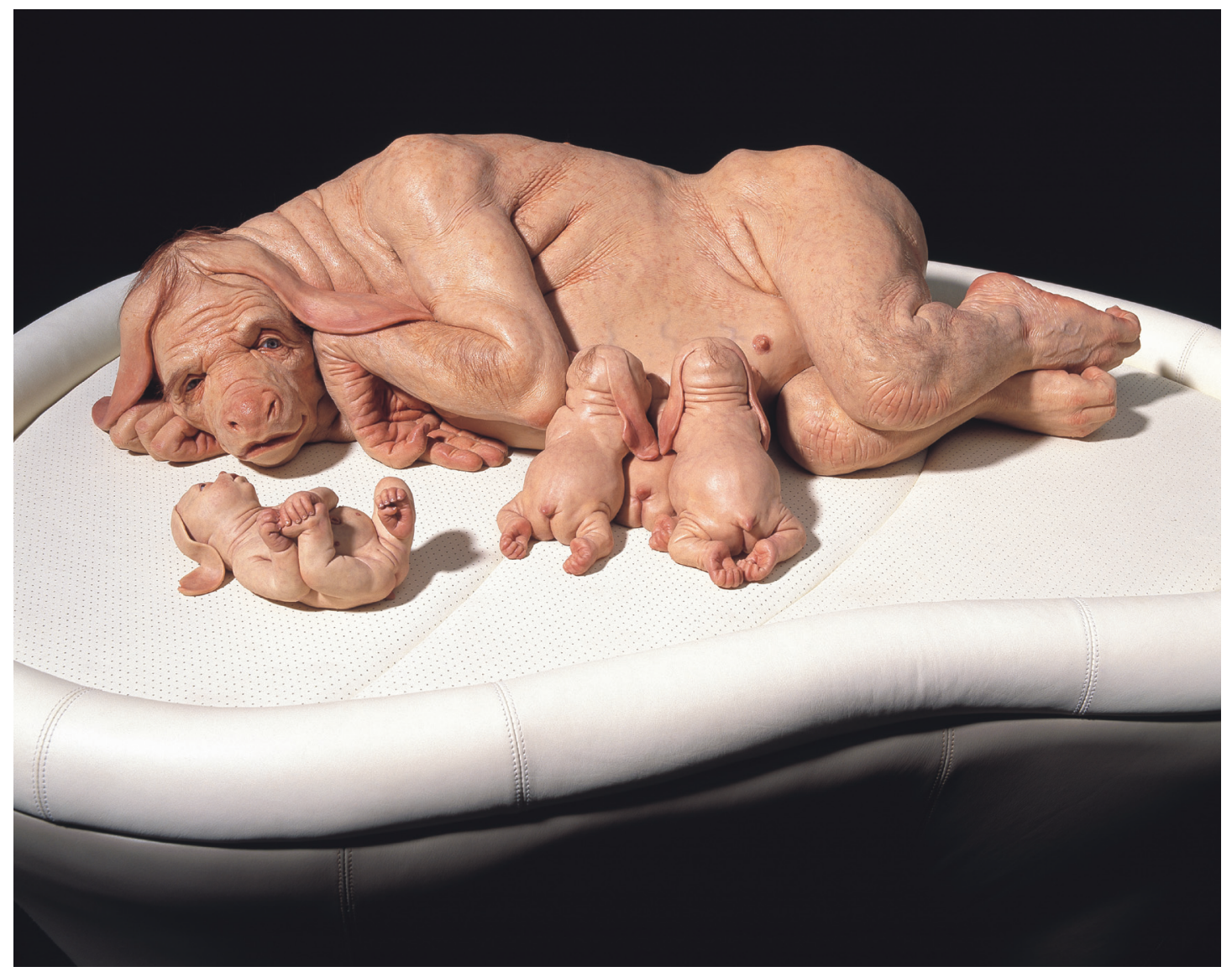

2 Patricia Piccinini, The Young Family (2002). Silicone, fibreglass, leather, human hair, plywood. $85 \mathrm{~cm}$ x $150 \mathrm{~cm} \times 120 \mathrm{~cm}$ approx. Photo: Graham Baring.

benign curiosity onto the viewers themselves, and present creatures exploited as endearing pets and curiosities for infantile and overly curious human masters.

\section{Human family and nature}

In the title of the installation, We are Family, Piccinini toys with the linguistic concept of familiarity, family and familial relationships. The notion of family in the sense of taxonomic rank is evoked, in that the creatures presented are genetically related to humans. The Young Family (2) represents is a small nuclear family, which immediately draws attention to their simulated humanness and the relationships between pets and their owners, in that petowners often see their pets as 'a part of the family'. The nature of the family and the family environment is dealt with in these works. In Piccinini's family there is no private space, no retreat of normalcy for these creatures to return to. They are exposed and displayed as art-pieces. In this way the artist also questions the idea of a 'normal' family environment, and the planes of interaction between the nuclear family and the outside world.

The denial of the norm in these works extends beyond the mere flesh-and-blood principles of family, however. The children in her works are depicted as innocent, but afforded a position of great power and dominance over the genetically enfeebled, the reduced other. Thus they become human in that they dominate the other creatures in the works with impunity, proven by their stark juxtaposition with the 'monsters'. However, the creatures are human enough to evoke a deep sense of sympathy and pity for them.

The interplay of normalcy and grotesqueness invokes the dialectic of natural and artificial. Yet, the lifeless stasis of these synthetic (but realistic-looking) children destabilises a straightforward reading of the 


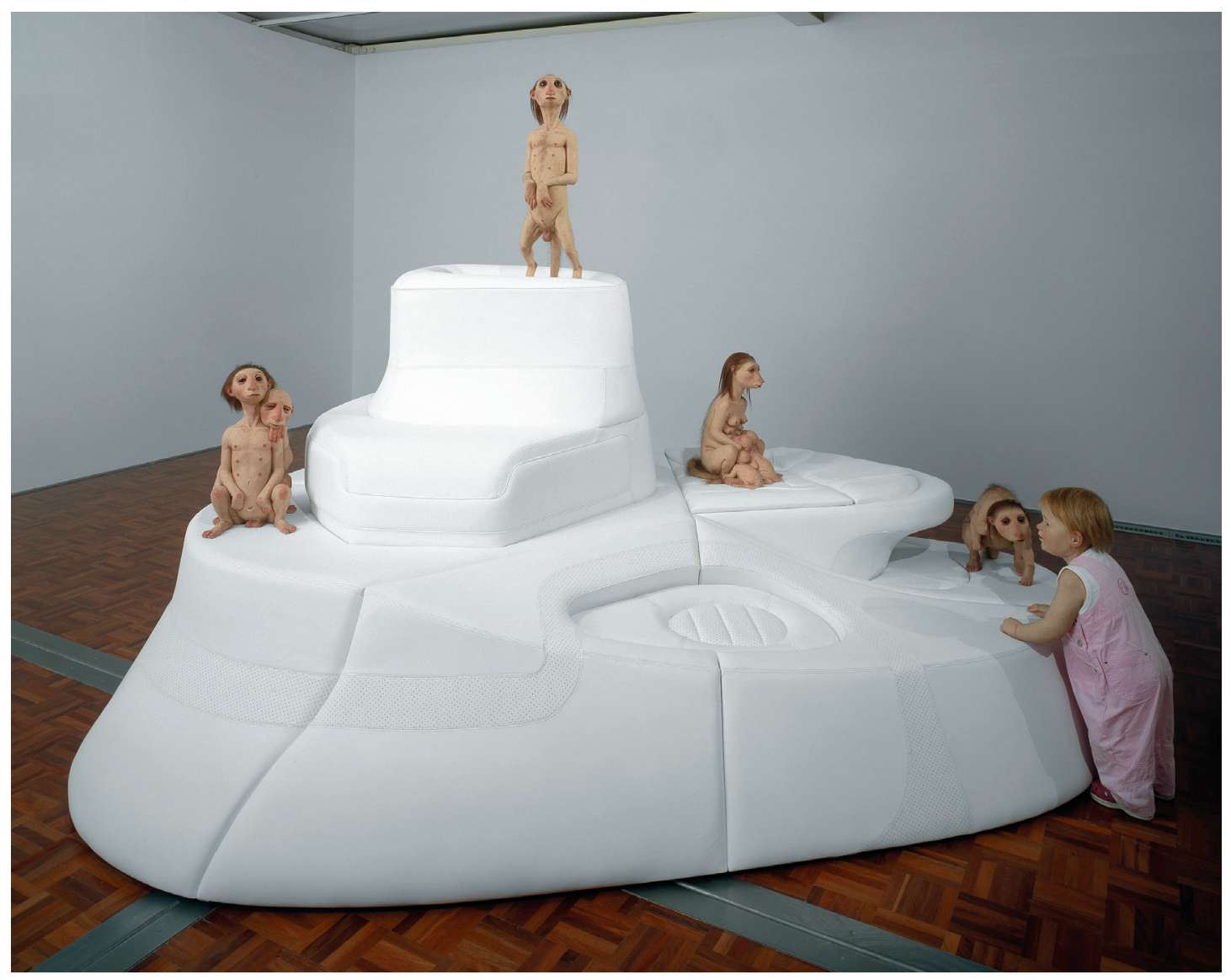

3 (Above and below) Patricia Piccinini, Leather Landscape (2003). Silicone, acrylic, leather, human hair, timber. $290 \mathrm{~cm} \times 175 \mathrm{~cm} x$ $165 \mathrm{~cm}$. Photo: Graham Baring.

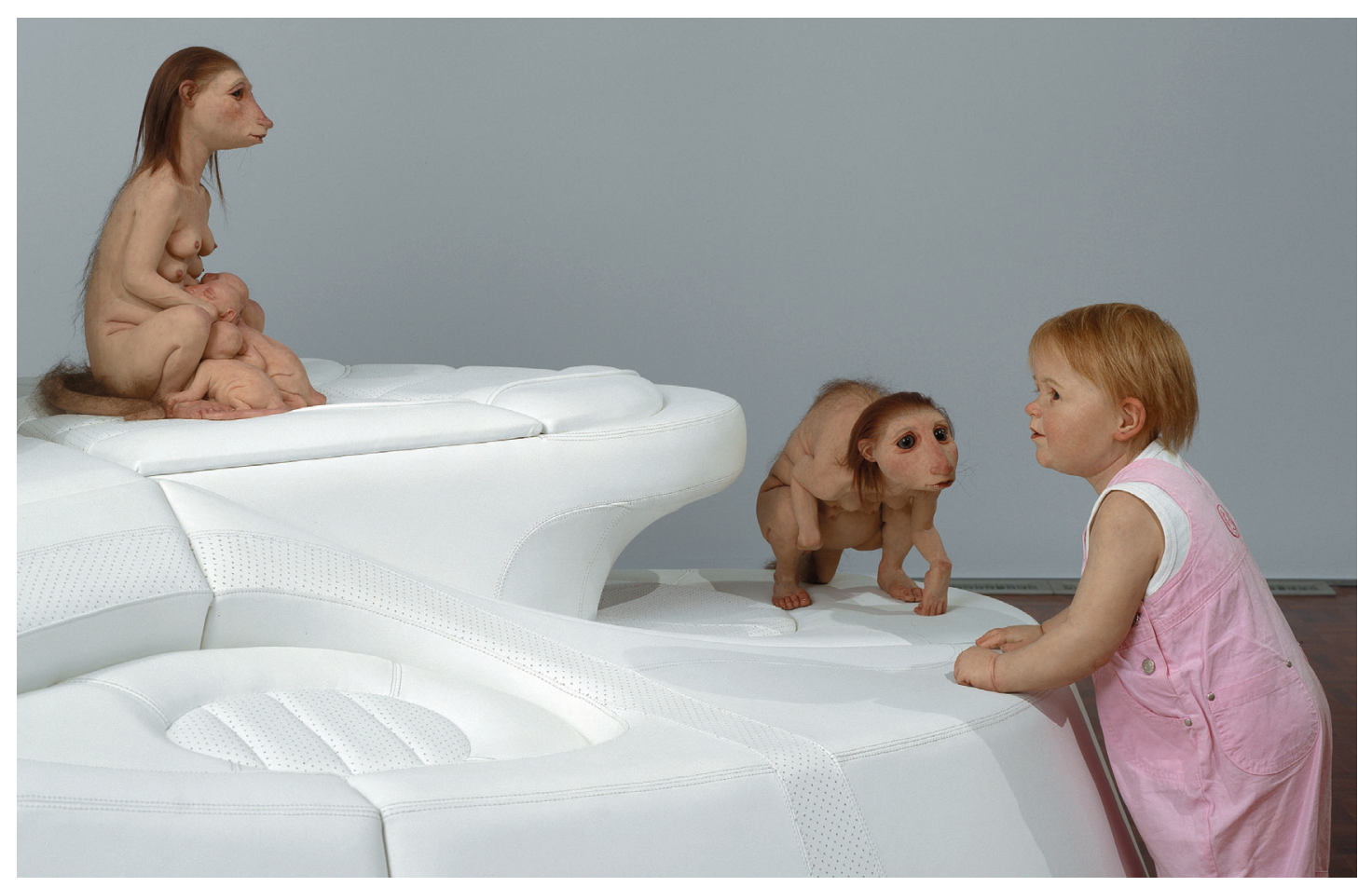


work. Ostensibly, it would seem that Piccinini has presented us with the traditional trope of (normal $=$ natural) and (grotesque $=$ artificial) However, this cannot withstand the fact that the sculpture clearly shows that it is not so much the monsters that are abhorrent, but the children, who are looking on with such wideeyed innocence, oblivious to the fact that the situation should seem abhorrent. Thus this idea is subverted in favour of a far more seditious dialogue.

At this stage, it is useful to examine Haraway's position of nature more thoroughly. Haraway (1991a:296) describes the dilemma of the human relationship with nature as follows:

Nature is for me ... one of those impossible things characterized by Gayatri Spivak as that which we cannot not desire. Excruciatingly conscious of nature's discursive constitution as 'other' in the histories of colonialism, racism, sexism and class domination of many kinds, we nonetheless find in this problematic, ethno-specific, long-lived and mobile concept something we cannot do without, but can never 'have'. We must find another relationship to nature besides reification and possession.

According to Haraway (1991a:296), nature is 'made' by ourselves, our technology and our experience, through the mutually creative interplay of various 'artefacts' (the players on what she sees as the stage of nature) which are loaded with meaning to varying degrees. This rather pliable, almost Shakespearean view, allows for the possibility that even what we regard as the most aberrant perversion of nature - the genetic chimera - is a part of nature. The genetic homunculus must be considered under such a theory not only because it allows us to consider the homunculus beyond the confining and narrow strictures of scientific method, but also because it is a way to argue the homunculus as a position of post-humanity ${ }^{7}$, without becoming embroiled in ethical complexities.

Haraway's (1991a:332) contention is that knowledges are made, through dialectical processes such as self/other, nature/culture or human/not human: 'If organisms are natural objects, it is crucial to remember that organisms are not born; they are made in world-changing technoscientific practices by particular collective actors in particular times and places' (1991a:297). This equates nature, technology, culture and humanity on a homogenous plane of creative power, and gives each the ability to create or influence the creation of the Other, at least in terms of discourse. "The "collective", of which "nature" in any form is one example ... is always an artefact, always social, not because of some transcendental Social that explains science or vice versa, but because of its heterogeneous actants/actors.' This equity of creative power allows for the view that we make nature, just as nature makes us. Haraway seeks to naturalise the course of nature creating organism creating technology creating organism creating nature. Of course, this does not necessarily mean a physical creation of all organisms, but it is apt to take the discourse onto the topos of genetic cloning and cybernetics.

\section{Worlds and homes}

In her alchemic model, Haraway diverges from the traditional modes of viewing nature 'as that which is hidden and must be unveiled; as the "other" who/which offers origin, replenishment and service; as mother, nurse, or matrix, resource, or tool for the reproduction of man' (1991a:296). However, this view of nature as discourse is congruent with the idea of biology as a discourse between environment and organism, mind and organism, and mind and environment. Such dualism can be taken further in the discourse of desire surrounding nature, by extending it to concepts of belonging, land and home.

In Leather Landscape (3) the creatures' environment, a miniature white landscape reminiscent of a zoo habitat, is itself a landscape, but it becomes awash with colonial metaphor. However, the creatures do not have and never had an original habitat or home, so either we must imperialistically consider that this is their 'natural' environment simply by virtue of the fact that they had none to begin with, or we must consider that the creatures' genetic parents have been disenfranchised in the most heinous way - two species have been displaced from their natural habitats or homelands, and their offspring have been denied the right of heritage. Similarly, Haraway's cyborg 'does not expect its father to save it through a restoration of the garden ... [since it] would not recognize the Garden of Eden; it is not made of mud and cannot dream of returning to dust' (1991b: 29). 
The fact that the visual real has become amended by virtual creatures such as the ones in Figure 3, in the Baudrillardian (1996:13) sense, means that although the concepts of world and 'the real' are constructs already, the human imagination has been active in altering and adding to the real; therefore it becomes a fully human world assuming its full meaning in being imaginative and fictive. According to Baudrillard (1996:13), the world is only appearance and will always remain the ultimate mystery, the enigma. In fact, the world has disappeared and is radical illusion (Baudrillard 1996:16): the real actually consists in the discourse on the real. In The perfect crime, Baudrillard (1996:109) presents a nostalgic loss of a human sense of world and teleology in the artificial encounter:

With the Virtual, we enter not only upon the era of the liquidation of the Real and the Referential, but that of the extermination of the Other.

It is the equivalent of an ethnic cleansing which would not just affect particular populations but unrelentingly pursue all forms of otherness.

The otherness of death - staved off by unrelenting medical intervention.

Of the face and the body - run to earth by plastic surgery.

Of the world - dispelled by Virtual Reality.

Of every one - which will one day be abolished by the cloning of individual cells. And, quite simply, of the other, currently undergoing dilution in perpetual communication.

If information is the site of the perfect crime against reality, communication is the site of the perfect crime against otherness.

No more other: communication.

No more enemy: negotiation.

No more predators: conviviality.

No more negativity: absolute positivity.

No more death: the immortality of the clone.

No more otherness: identity and

difference.

No more seduction: sexual in-difference. No more illusion: hyperreality, Virtual

Reality.

No more secret: transparency.

No more destiny.

The perfect crime.
Andreas Huyssen postulates that the search for the real has become utopian (1995:101), and refers to Baudrillard's 'astrophysical imagery [that] betrays his hidden desire: it expresses nothing so much as the desire for the real after the end of television' (1995:90). The process of the 'amendment' of the real entails not denial of the human real, but an extension of the boundaries of being human for the viewer.

Similarly, in Leather Landscape, the viewer is enticed to relinquish his/her ideas about the ontologies of being human in the complicity of the simulacrum of the real. The viewer is as much a monster as the creature in the false habitat. Herein lies the irony of the work - the viewer's monstrous nature is reflected in the eyes of the pitiful creatures and he/she is forced not only to sympathise with the creatures, but to contemplate the power exchange.

\section{The post-human and ownership}

The question of ownership - no longer what, but who is owned - is critical to Piccinini's We are Family. Both ghastly and endearing, the pets in Leather Landscape are a reminder of the failure of technocracy in the collapse of the value of individual rights, which Francis Fukuyama (2002), a pre-eminent scholar in the field of bio-ethics, sees as inherent to the genetic project. Haraway (1992:324), in discussing the distribution of knowledge with regards to AIDS and other terminal illnesses, strikes on the dilemma of distribution of knowledge by the technocracy and causes us to examine the homunculus in terms of its arbitration and the access it would have to the technologies that provide prosthesis, as well as who would have access to them:

\footnotetext{
Unable to police the same boundaries separating insiders and outsiders, the world of biomedical research will never be the same again. The changes range across the epistemological, the commercial, the juridical and the spiritual domains. What are the consequences of the simultaneous challenges to expert monopoly of knowledge and insistence on both the rapid improvement of the biomedical knowledge base and the equitable mass distribution of its fruits? How will the patently amodern hybrids of healing practices cohabit in the emerging social body? And, who will live and die as a result of these very non-innocent practices?
} 
Since little public forum exists where the ethics of genetic technologies may be discussed, the laws that govern genetic science are opaque to the public, and future genetic research goals (and even past research) cannot easily be scrutinised by the public. The Piccinini sculptures compel the viewer to critically engage with genetic science as a new dominant social force, and become involved in the mystique of the homunculus. Although the sculptures present the viewer with possibilities and future realities, these remain feasible consequences of the biotechnology revolution. Piccinini's creatures are so frighteningly aberrant because they represent the arm of genetic science that is not geared towards the betterment of humanity, as it is understood in a general sense, but instead towards the satisfaction of curiosity. It is not the cure for cancer that humans fear; rather it is the route that science takes to get there. Her creatures show the death and transfiguration of humanness into something terrible and pitiable, and the artist shows the viewer the reverse side of the purification and perfection of humanity.

Terms of ownership, identity and corporate and human rights have to be renegotiated in light of the fact that homunculi will eventually become corporate products. This is because genetic homunculi, or human 'upgrades' (that are likely to become mandatory or perhaps even necessary for even the most basic jobs) will be manufactured by the businesses we give the rights to do so. Such re-negotiating will require the complete restructuring of our views on what it means to be (post)human, as well as our relationship with nature, and will be a consequence of the outcome of our present debates on the matter. The current Western, capitalist approach to nature is still largely interventionist, and this approach to nature informs the creation of a genetic homunculus, but it must be re-evaluated for the homunculus itself, because of the fact that for the first time the arbiters of the technology will themselves be the technology.

For homunculi like these, questions of race, gender and even culture become questions no longer of nature but of choice - choices made by the imperialising Other, but also by the homunculus (gene-altering therapy and cybernetic extensionism are the technologies of the genetic homunculus). This can be taken to mean that what are, for humans, issues of dynamic cultural discussion will become, for the genetic homunculus, a very culturally loaded form of gene-aesthetics. By presenting terrible abortions of form that look like animal/ human hybrids, Piccinini presents a conclusion of the industrial narrative of history that is presented in the genetic project. It is within this paradigm that the viewer must somehow come to terms with her homunculi.

Humans have already witnessed assisted pregnancies, in-vitro fertilisation and preselective genetics. The created Other, the technological self and the technologically created are specific realities of contemporary science and, very soon, will be features of modern life as aspects of genetic technology filter through to the public. As beings with the power to control technology and also subvert the purposes of the technocracy through raising awareness, it falls to every person to make decisions about where we choose to take the technology that will bring about an intelligent homunculus. The genetic homunculus already threatens human sovereignty of rights in the continual denial of basic human liberties that genetic homunculi face in research conditions (MacDonald-Glenn 2003:251). Muotri et al. (2005) observe that their part-human chimera exists purely as a research object, much like any laboratory rat. Genetics researchers control the means of life and death of their subjects within the laboratory, but this research has consequences outside the laboratory too.

This refiguring of the modes of life and death, evident in Piccinini's work, is leading humanity towards a biotechnological mode of procreation and reproduction. After all, genetics research will undoubtedly also yield great marvels as well as great horrors, but this is not to say that the genetic homunculus will be free of its Frankensteinian stigma either way.

\section{Closing}

In We are Family, Piccinini's hyper-realistic homunculi sculptures are presented as abject: wretched and pathetic animal/human chimeras exploited as 'endearing' pets and curiosities for infantile and overly curious human masters. This might suggest that the genetic homunculus has specific and real social consequences for humanity in the near future. Genetic manipulation renders questions of race, beauty and even sex malleable, and as such imperialising structures of belonging 
and the owner/owned become subverted. As such, it would seem that human beings have progressed to a state where their control over the environment, their corporeal influence on it, and the influence it has on them, has changed their ideas about themselves and their ultimate destinies.

\section{References}

Abrams, J. 2004. Pragmatism, artificial intelligence and post-human bioethics. Human Studies 27(1):241-258.

Baudrillard, J. 1995. Simulacra and simulations, trans. S. Glaser. Ann Arbor: University of Michigan Press.

- 1996. The perfect crime, trans. C. Turner. London: Verso.

Baylis, F. and S. Robert. 2007. Part-human chimeras: Worrying the facts, probing the ethics. The American Journal of Bioethics 7(5):41-45.

Drummond, D., R. Grove-White and B. Szerszynski, eds. 2003. Re-ordering nature: Theology, society and the new genetics. London: T \& T Clark.

Eliade, M. 1971. The forge and the crucible: The origins and structures of alchemy. New York: Harper Torchbooks.

Fukuyama, F. 2002. Our posthuman future: Consequences of the biotechnology revolution. New York: Farrar Straus and Giroux.

Haraway, D. 1991a. Simians, cyborgs and women: The reinvention of nature. New York: Routledge.

_. 1991b. A manifesto for cyborgs: Science, technology and socialist feminism in the 1980s. First published in the Socialist Review 80(15) 2 (March-April, 1985). Later published in the Socialist Review Collective. Unfinished business: 20 years of socialist review (London: Verso 1991). This version reproduced in D. Trend, ed. 2001. Reading digital culture. Massachusetts and Oxford: Blackwell.

_. 1992. Cultural studies, ed. L. Grossberg, C. Nelson \& P. Treichler, 295-337. New York: Routledge.

Holmyard, E., ed. 1928. The Arabic works of Jabir ibn Hayyan, trans. R. Russell. New York: Kessinger Publishing.

Jones, A. 2001. The body and technology. Art Journal 60(3):20-39.

Jung, C. 1963. The collected works of CG Jung, Volume 14: Mysterium Coniunctionis. London: Routledge \& Kegan Paul.

MacDonald-Glenn, L. 2003. When pigs fly? Legal and ethical issues in transgenics and the creation of chimeras. The Physiologist 46(5):251-255.

Muotri, A., K. Nakashima, A. Toni, V. Sandler and F. Gage. 2005. Development of functional human embryonic stem cell-derived neurons in mouse brain. PNAS 102(51):18644-18648.
Newman, W. 2004. Promethean ambitions: Alchemy and the quest to perfect nature. Chicago: University of Chicago Press.

Pepperell, R. 1995. The post-human condition. Oxford: Intellect.

Peters, T. 2003. Playing God? Genetic determinism and human freedom. New York: Routledge.

Piccinini, P. [Sa]. [0]. http://www.patriciapiccinini. net/wearefamily/ (accessed 15 April 2008).

Robert, J. 2002. Regulating the creation of novel beings. Health Law Review 11(1):14-19.

\section{Notes}

1 This article was submitted in partial fulfilment of the requirements for the degree of MA in Visual Studies in the Faculty of Humanities at the University of Pretoria. Andrew Smith was supervised by Prof Elfriede Dreyer. All images in this article were reproduced by kind permission of the artist.

2 Ancient Greek tradition holds that Pygmalion, King of Cyprus, created an ivory sculpture so perfect he fell in love with it, prompting Athena to bring it to life. Although the creature is created by his hand, it is given the spark of life by a divine element. The usurpation of the gods' power has also been a feature of mythology. When Zeus withheld fire from the people of the earth, Prometheus stole it from him and gave it to his mortal creations. Hebrew mythology tells of the golem, a mindless, soulless construct shaped from clay to protect or serve its creator; the word truth is etched into its forehead to bring it to life. In the case of the golem, the inanimate clay can only be brought to life by the holiest of rabbis. The most sacred technology has always been stolen from or given by the gods.

3 The utopian view in post-human theory is centred on the seamless integration of natural and artificial, but the utopian teleology of this amalgam is that it should be seen as natural, while a dystopian outcome (or rather the lack of any positive outcome) may reveal that the fusion is in fact supreme artificiality. The post-human design may ultimately be revealed as utopia - a nowhere place. The genetic homunculus must be examined as a kind of utopia in Haraway's (1991) sense of nature as a topic place for a forum of ideas and exchange of rhetoric, due to the fact that as yet, an intelligent genetic homunculus remains merely a theoretical concept.

4 The term 'homunculus' refers to the humancreated being - a notion established by the medieval physician and mystic Paracelsus, as a creature created out of human generative fluids by the alchemist's hand, through his 
technology. Taken from the Latin for 'small man' (homo $=$ man + culus $=$ diminutive suffix), 'homunculus' is the term used by pre-modern Western alchemists to describe the product of human genesis in the retort (most often through the cultivation of human semen). For this reason it is practical to appropriate the term to refer to the genetic endeavours of modern science, which leads to its other definition. Social objections to the dehumanisation that human genetic engineering represents are similar to those raised by the opponents of Paracelsus (Newman 2004). Judaeo-Christian creation mythology details the creation of the male before the female, as does Hesiodic Greek Myth. The alchemic conception of the homunculus follows these ancient precepts, in that the Biblical Adam was used in many instances to symbolise aspects of the alchemical adept's transcendent spirit (Jung 1963). Since the homunculus was intended as a means of spiritual transformation, the first homunculus would be a kind of pseudoAdam in its own right. Although the treatises do not preclude the creation of female homunculi (in fact, quite the contrary), the concept's origins are firmly rooted in masculine traditions.
5 Alchemy and the concept of the homunculus are part of a dominantly male-oriented philosophy and there were very few female alchemists until the pre-modern era, the Egyptian monarch, Cleopatra the notable exception. The homunculus's genesis outside the womb serves to further remove it from the feminine.

6 The significance of the alchemist's tools is affirmed by the sanctity of the ores as well as the sacred re-enactment of the natural process. They serve to simulate the gestation of the ore in the womb of the Earth, hastening its journey to gold. The alchemist's vessels and retorts were the sacred representations of the earth's womb.

7 Post-human theory of nature articulates the genetic homunculus as a post-human, artificial technological being, with a unique genesis based in the spheres of both nature and technology. With the aim of contextualising alchemy within a post-human ideological framework, American biologist Donna Haraway's (1992) theory of nature as a topic-place is used to propose a kind of profane sacred nature as a framework for the creation of the genetically engineered being - a proposal of a synthesis of nature and technology. 